\title{
SEASONAL DIFFERENCE IN RESPONSES OF BODY FLUIDS TO HEAT STRESS
}

\author{
Taketoshi Morimoto*, Keizo Shiraki**, and Masami Asayama*** \\ *Department of Physiology, Kyoto Prefectural University of Medicine, Kamigyoku, Kyoto \\ **Department of Nutrition, Tokushima University, School of Medicine, \\ Kuramotocho, Tokushima \\ *** Department of Hygiene, Kyoto Prefectural University of Medicine, \\ Kamigyoku, Kyoto
}

\begin{abstract}
Summary Ten male volunteers were subjected to heat stress in winter and in summer and changes in volume and composition of the body fluids were followed for about $24 \mathrm{hr}$ afterwards.

In summer, sodium and chloride concentration in serum and serum osmolality increased most just after sweating and returned to the control value within a day of heat exposure, while in winter they were highest three hours after sweating, and the effect of heat stress lasted until the following morning. Both in winter and in summer, the circulating blood volume tended to increase even when hemoconcentration was obvious. Plasma protein which was determined in summer experiments showed an increase after heat stress and the importance of plasma protein in maintaining the circulating blood volume during or after sweating and its contribution to so called voluntary dehydration are discussed.
\end{abstract}

The volume and composition of the body fluids are homeostatically maintained with a very high precision. Sweat, secreted to regulate body temperature, becomes a threat to homeostasis of the body fluid, and many reports have been published on changes of body fluids caused by sweating (GLICKMAN et al., 1941; Ladell, 1949; Itoh, 1953; Senay and Christensen, 1965, 1968; Senay, 1968, 1970, 1972). According to the review by BASS and HeNSCHEL (1956), an acute heat stress elicits responses which, in the absence of dehydration, result in increased plasma and blood volumes with little change in their compositions, although the behaviors of extracellular and interstitial fluids are still controversial. The series of reports by SENAY indicates that the increase in plasma or blood volume during an acute heat stress cannot be explained by a simple dilution of the intravascular contents.

Hemodilution in summer and hemoconcentration in winter, together with

Received for publication November 5, 1974

森本武利, 白木啓三, 朝山正己 
a marked increase in the sweat rate in summer have also been reported (YoSHIMURA, 1958, 1960; MORIMOTo et al., 1969).

In this work the mechanism of regulation of the body fluid under heat stress was studied by simultaneous measurements of the size of body fluid compartments and blood constituents. The responses of body fluids to sweat loss were also compared between summer and winter.

\section{METHODS}

Ten male student volunteers, 19-24 years of age, took part in the experiments which were performed in January and again in August. The experimental schedule was as follows: The subjects reported to the laboratory at 20:00 hr in the evening before the day of experiments and subsequently their water intake was restricted. They stayed overnight in a room maintained at about $25^{\circ} \mathrm{C}$. They woke up at 06: $00 \mathrm{hr}$ and after a light breakfast, voided urine and took $50 \mathrm{ml}$ of $\mathrm{D}_{2} \mathrm{O}$ (Showa Denko, Tokyo) with $300 \mathrm{ml}$ of tepid tea. In experiments in August subjects were also injected with $1 \mathrm{mCi}$ of tritium water (Départment des Radioéléments, France) just after breakfast. Thereafter, their urine samples were collected every $30 \mathrm{~min}$ for $3 \mathrm{hr}$, and the last samples were used for total body water determinations. At around 10:00 hr, control measurements were made of total body water (TBW), extracellular fluid volume (ECF), circulating plasma volume (CPV), circulating blood volume (CBV), hematocrit, whole blood water content, plasma water content (summer only), serum osmolality, serum concentrations of sodium, chloride, and potassium and plasma protein concentration (summer only).

Soon after the collection of first blood sample, subjects went into a hot room, maintained at $42^{\circ} \pm 1{ }^{\circ} \mathrm{C}, 60 \pm 5 \%$ relative humidity. They rested on a chair in the room for $30 \mathrm{~min}$, and then worked and rested for alternate $10 \mathrm{~min}$ intervals for $90 \mathrm{~min}$. Their work consisted of stepping up onto and down off a 26-cmhigh bench 25 times/min. Sweat loss was determined by weighing the subjects on platform scales measuring with an accuracy of $\pm 2.5 \mathrm{~g}$. Then the subjects moved to a room maintained at about $25^{\circ} \mathrm{C}$, and all the same measurements described above except TBW were made (around 13:00 hr). Subjects rested for another $3 \mathrm{hr}$ in the room at $25^{\circ} \mathrm{C}$ and then the third measurements were performed at around 16:00 hr. Water intake was still restricted during this period. After the third measurements, subjects were given a light supper of fixed water and salts contents. Then water was allowed ad libitum but the amount imbided was recorded. The fourth measurements were performed about $3 \mathrm{hr}$ after supper at around 20:00 hr, and the fifth measurements were made under basal conditions the following morning. The time schedule of the experiment is summarized at the top of Fig. 1. Urine collection and body weight measurements were performed after taking blood samples for calculation of water balance. 
The methods used were as follows: TBW was determined by the tritium dilution method described by CARDus et al. (1969) in experiments in summer. In experiments in winter, determination of $\mathrm{D}_{2} \mathrm{O}$ (ARNETT and MCC. DugGLEBY, 1963) was unsuccessful and the normal value reported, i.e. $65 \%$ of the body weight, was used. The TBW in the second to fifth measurements was calculated from the value of the first measurements (control values) and water balance. ECF was estimated by means of the ${ }^{35} \mathrm{SO}_{4}$ dilution method. $30 \mu \mathrm{Ci}$ of $\mathrm{Na}_{2}{ }^{35} \mathrm{SO}_{4}$ (Dainabot, Tokyo) was infused $30 \mathrm{~min}$ before blood sampling as described by ALBERT et al. (1968). CPV was determined by means of the ${ }^{125}$ I-RISA dilution method. In this case $3 \mu \mathrm{Ci}$ of ${ }^{125} \mathrm{I}$-RISA (Dainabot, Tokyo) was injected and $10 \mathrm{~min}$ value of the activity in plasma was used for the calculation of CPV. The validity of repeated use of this method in the same subject within a day has been verified so long as it is less then five times (SHIRAKI et al., 1968). CBV was calculated from $\mathrm{CPV}$ and the hematocrit value. The tritium concentration in the urine was determined after distillation (SIMPSON and GREENING, 1960) using a liquid scintillation counter (Packard, U.S.A.). ${ }^{35} \mathrm{SO}_{4}$ concentration of blood and urine samples were measured in clear, protein-free solution. The activity of ${ }^{35} \mathrm{~S}$ was counted in the same liquid scintillation counter discriminating counts for tritium. ${ }^{125}$ I-concentration was measured in a welltype scintillation counter (Nuclear Chicago, U.S.A.).

The blood samples were used for measurements of ECF volume, CPV, hematocrit (by capillary tube method, uncorrected for trapped plasma) and whole blood water content (by the constant dry weight method of KURODA, 1969). Using serum, the osmolality (Fiske Osmometer), sodium and potassium (Baird flame photometer) and chloride concentrations (Buchler-Cotlove chloride titrator) were determined, while using plasma, plasma water content (by the constant dry weight method, summer only), the total protein concentration (semimicroKijeldahal method) were measured and total protein was subjected to electrophoresis on cellulose acetate by using an oxoide membrane.

\section{RESULTS}

The results are expressed as deviations from the control values measured at 10: $00 \mathrm{hr}$ and data were given as the means and standard deviations of values for ten subjects.

Figure 1 shows changes in body weight, hematocrit, blood water content and water balance. The average decrease in body weight due to the heat exposure was $0.96 \mathrm{~kg}$ in winter and $1.42 \mathrm{~kg}$ in summer, the seasonal difference being statistically significant $(P<0.001)$. In both seasons, there was an additional loss of about $0.5 \mathrm{~kg}$ during the three-hour rest period. After supper, when water intake was allowed ad libitum, subjects gained $0.70 \mathrm{~kg}$ in weight at $20: 00 \mathrm{hr}$ in winter and $1.20 \mathrm{~kg}$ in summer. During the experiment, they lost $1.30 \mathrm{~kg}$ body weight 


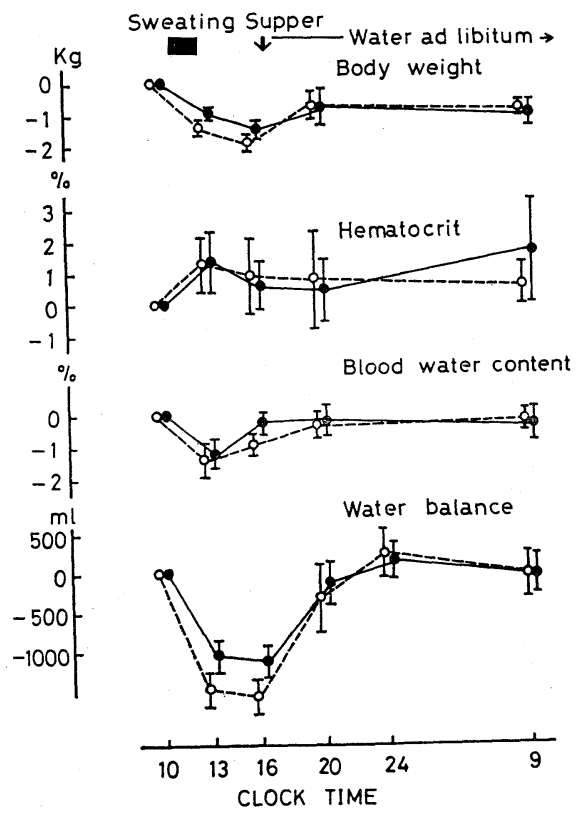

Fig. 1. Changes in body weight, hematocrit and blood water content from the control value measured at 10:00 hr and water balance. Closed circles and solid lines represent results in winter and open circles and dotted lines indicate results in summer. Points and bars represent means and standard deviations of values in 10 subjects.

in winter and $0.83 \mathrm{~kg}$ in summer. The decreases in body weight were all statistically highly significant $(P<0.005$ for $20: 00 \mathrm{hr}$ in winter, $P<0.001$ for the rest). On the other hand, water balance, calculated from the sweat loss, urine volume and water intake, was regained within the day of the experiment. The maximal negative water balance was observed at $16: 00 \mathrm{hr}$ in both seasons; $-1,120 \mathrm{ml}$ in winter and $-1,574 \mathrm{ml}$ in summer. This negative balance was reduced to $-132 \mathrm{ml}$ in winter and $-333 \mathrm{ml}$ in summer within $3 \mathrm{hr}$ after drinking water ad libitum. At 24: $00 \mathrm{hr}$, the balance became positive; $145 \mathrm{ml}$ in winter and $239 \mathrm{ml}$ in summer. The following morning, the balance was almost zero, i.e. $-18 \mathrm{ml}$ in winter and $-47 \mathrm{ml}$ in summer.

The hematocrit increased by about $1.3 \%$ at $13: 00 \mathrm{hr}$ both in winter and summer, but within $3 \mathrm{hr}$ after heat exposure, it decreased to within $1 \%$ and then remained rather steady, except for the value at 09:00 hr in winter. Measurements at 13:00 hr were made at about $45 \mathrm{~min}$ after sweating because measurement of the ECF volume took about $30 \mathrm{~min}$. Before injection of ${ }^{35} \mathrm{SO}_{4}$ a small amount of blood was drawn as a pre-mix sample, and the hematocrit value of blood sample was measured immediately after sweating. The differences of the hematocrit value from the control were $2.2 \%$ in winter and $3.4 \%$ in summer, which 
were almost twice as much as those obtained 30 min later.

The water content in whole blood and the hematocrit changed in comparable magnitudes but in the opposite direction. In winter the decreases in whole blood water content was $1.22 \%$ at $13: 00 \mathrm{hr}(P<0.001), 0.29 \%$ at $16: 00 \mathrm{hr}(P<0.05)$, $0.19 \%$ at $20: 00 \mathrm{hr}$ (not significant) and $0.34 \%$ at $09: 00 \mathrm{hr}$ (not significant), and in summer, the corresponding values were $1.4 \%(P<0.001), 0.94 \%(P<0.001)$, $0.32 \%(P<0.05)$ and $0.22 \%$ (not significant). The plasma water content was measured only in the summer experiment. It decreased by $0.97 \%$ at $13: 00 \mathrm{hr}$ $(P<0.001), 0.42 \%$ at $16: 00 \mathrm{hr}(P<0.001), 0.07 \%$ at $20: 00 \mathrm{hr}$ (not significant) and $0.05 \%$ at $09: 00 \mathrm{hr}$ (not significant).

With regard to seasonal differences in responses to heat stress, statistically significant differences were observed in the following items: the decrease in the blood water content at $16: 00 \mathrm{hr}(P<0.001)$, decrease in body weight at 13: $00 \mathrm{hr}(P<0.001)$ and negative water balance at 13:00 $\mathrm{hr}(P<0.005)$ and at 16: $00 \mathrm{hr}(P<0.005)$.

Results on serum osmolality and ion concentrations are shown in Fig. 2. In winter the increase of serum osmolality was higher at 16:00 hr than at 13:00 hr and thereafter the rate of increase decreased only slightly. On the other hand, in summer the increase at 13:00 hr was more than double than in winter, but the value decreased towards the control values after 16:00 hr. All the increments

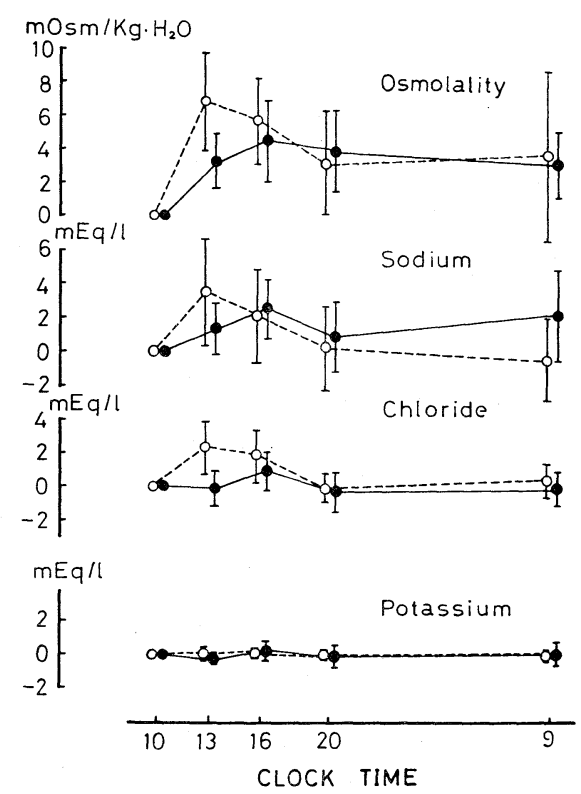

Fig. 2. Changes in serum electrolytes in winter (closed circles and solid lines) and in summer (open circles and dotted lines). Points and bars are means and standard deviations of values in 10 subjects. 
from control values were highly significant $(P<0.001)$ except for those at $20: 00 \mathrm{hr}$ $(P<0.02)$ and 09: $00 \mathrm{hr}(P<0.05)$ in summer. Serum sodium concentration showed similar changes to the osmolality, although the significances of the differences were much less and the values at 20:00 hr in both seasons and at 09:00 $\mathrm{hr}$ in summer were not significant. The change in the chloride concentration was slightly different, the increase soon after sweating being less than that of sodium. In winter, chloride did not show any increase except at 16:00 $\mathrm{hr}(0.9 \mathrm{mEq} / \mathrm{liter}$; $P<0.005)$, and in summer, chloride increased by $2.3 \mathrm{mEq} /$ liter $(P<0.005)$ while sodium increased by $3.5 \mathrm{mEq} /$ liter $(P<0.01)$ at $13: 00 \mathrm{hr}$. At 16:00 hr the increase in chloride was $1.8 \mathrm{mEq} /$ liter $(P<0.005)$ and that of sodium was $2.1 \mathrm{mEq} /$ liter $(P<0.02)$. Serum potassium did not show any change throughout the experiments.

Seasonal differences after heat loading were observed in the increase in serum osmolality at 13: $00 \mathrm{hr}(P<0.01)$, and at 16:00 hr $(P<0.02)$. The change in serum sodium concentration was significantly different only at $09: 00 \mathrm{hr}(P<$ $0.05)$, while that of chloride were significantly higher in summer at 13:00 hr $(P<0.01)$ and at 16: $00 \mathrm{hr}(P<0.02)$.

Figure 3 shows changes in total plasma protein, albumin, total globulin and the $\mathrm{A} / \mathrm{G}$ ratio determined in the summer experiment. The increase of total protein at 13:00 and 16:00 hr were both significant $(P<0.001)$, and thereafter

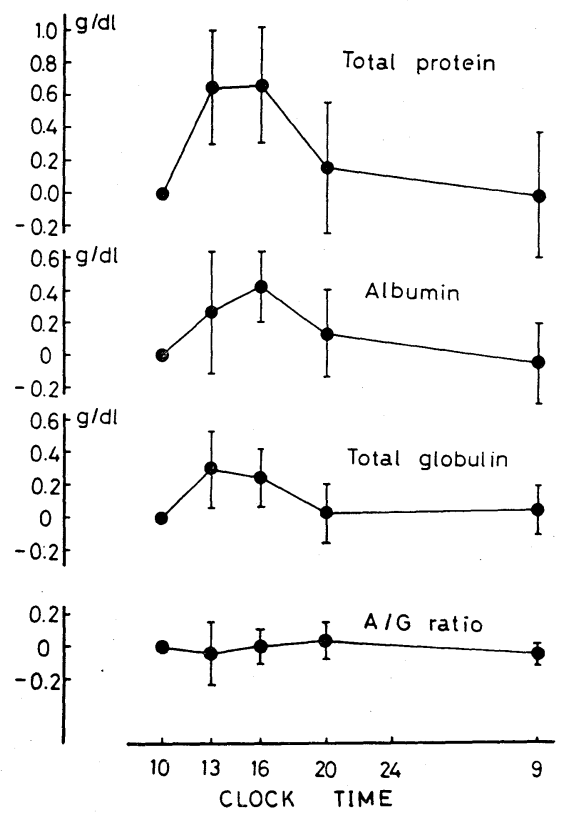

Fig. 3. Changes in plasma protein after sweating. Results were obtained in summer. Points and bars are means and standard deviations of values in 10 subjects. 
returned towards the control value. Plasma albumin increased gradually until 16: $00 \mathrm{hr}$ and then decreased to the control value, and the increase was only significant at $16: 00 \mathrm{hr}(P<0.001)$. Total globulin showed a significant increase at both 13:00 $\mathrm{hr}(P<0.005)$ and 16:00 $\mathrm{hr}(P<0.001)$ but the $\mathrm{A} / \mathrm{G}$ ratio did not show any significant change.

The intracellular fluid volume (ICF) and interstitial fluid volume (ISF) were calculated from the values for the total body water (TBW), extracellular fluid volume (ECF) and circulating plasma volume (CPV), and the deviations from control values are plotted in Figs. 4 and 5. As seen from these figures, the TBW decreased remarkably by sweating and increased again on water intake, while the CPV tended to increase, especially in summer, even when the TBW was markedly decreased. The decreases in the TBW were $5.5 \mathrm{ml} / \mathrm{kg}$ at $13: 00 \mathrm{hr}(P<0.001)$, $8.4 \mathrm{ml} / \mathrm{kg}$ at $16: 00 \mathrm{hr}(P<0.001), 4.4 \mathrm{ml} / \mathrm{kg}$ at $20: 00 \mathrm{hr}(P<0.005)$ and $5.7 \mathrm{ml} /$ $\mathrm{kg}$ at $09: 00 \mathrm{hr}(P<0.001)$ in winter and in summer, the corresponding values were $7.8 \mathrm{ml} / \mathrm{kg}(P<0.001), 10.5 \mathrm{ml} / \mathrm{kg}(P<0.001), 3.6 \mathrm{ml} / \mathrm{kg}(P<0.005)$ and $4.5 \mathrm{ml} / \mathrm{kg}(P<0.001)$. Increases in the CPV were $0.3 \mathrm{ml} / \mathrm{kg}$ at $13: 00 \mathrm{hr}, 2.4 \mathrm{ml} / \mathrm{kg}$ at $16: 00 \mathrm{hr}, 5.5 \mathrm{ml} / \mathrm{kg}$ at $20: 00 \mathrm{hr}(P<0.05)$ and $1.0 \mathrm{ml} / \mathrm{kg}$ at $09: 00 \mathrm{hr}$ in winter and in summer the increases were $2.5 \mathrm{ml} / \mathrm{kg}$ at $13: 00 \mathrm{hr}, 2.6 \mathrm{ml} / \mathrm{kg}$ at $16: 00 \mathrm{hr}$, $6.3 \mathrm{ml} / \mathrm{kg}$ at $20: 00 \mathrm{hr}$ and $5.3 \mathrm{ml} / \mathrm{kg}$ at $09: 00 \mathrm{hr}$. The statistical significance was found only in the increase at $20: 00 \mathrm{hr}$ in winter. The circulating blood volume (CBV) calculated from the value of CPV and hematocrit increased more than twice as much as the CPV, especially at 13:00 hr and 16:00 hr in both seasons,

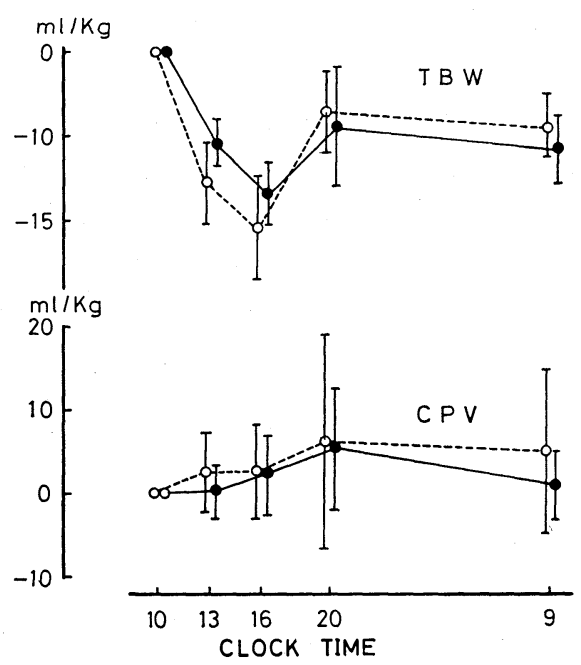

Fig. 4. Changes in total body water (TBW) and circulating plasma volume (CPV). Means and standard deviations of values in 10 subjects in winter (closed circles and solid line) and summer (open circles and solid line) are shown. 


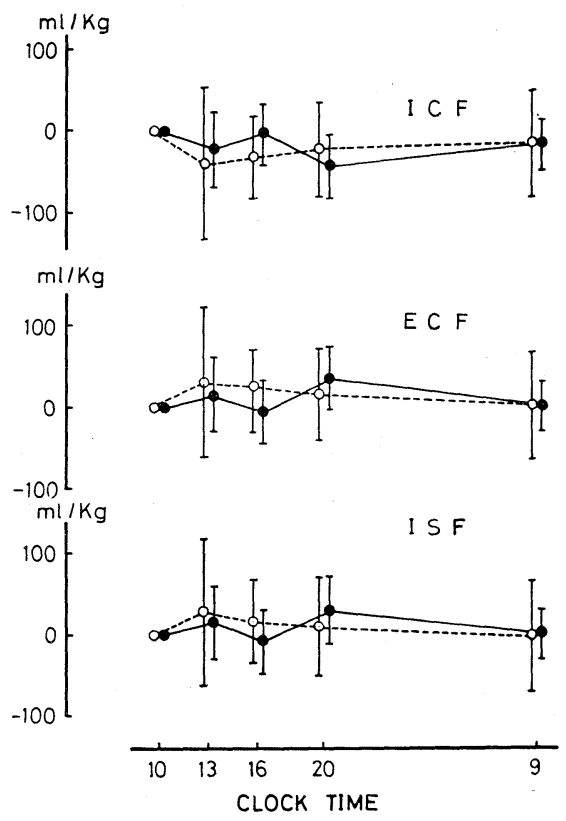

Fig. 5. Changes in intracellular fluid volume (ICF), extracellular fluid volume (ECF), and interstitial fluid volume (ISF). The ICF was calculated as TBW-ECF, and the ISF as ECF-CPV. Symbols are as in Fig. 4.

and the increase at $13: 00 \mathrm{hr}$ in summer $(9.5 \mathrm{ml} / \mathrm{kg})$ was highly statistically significant $(P<0.005)$.

Tendencies for the ICF to decrease and ECF and ISF to increase were observed especially in summer. Decreases in ICF were $21.9 \mathrm{ml} / \mathrm{kg}$ at $13: 00 \mathrm{hr}$, $2.6 \mathrm{ml} / \mathrm{kg}$ at $16: 00 \mathrm{hr}, 41.3 \mathrm{ml} / \mathrm{kg}$ at $20: 00 \mathrm{hr}(P<0.01)$ and $11.2 \mathrm{ml} / \mathrm{kg}$ at $09: 00 \mathrm{hr}$ in winter, while in summer decreases by $38.9 \mathrm{ml} / \mathrm{kg}$ at $13: 00 \mathrm{hr}, 31.0 \mathrm{ml} / \mathrm{kg}$ at 16: $00 \mathrm{hr}, 20.7 \mathrm{ml} / \mathrm{kg}$ at $20: 00 \mathrm{hr}$ and $10.2 \mathrm{ml} / \mathrm{kg}$ at $09: 00 \mathrm{hr}$ were observed. Statistical significance was observed only on the value at 20:00 hr in winter. Increases in ECF and ISF showed similar trends, and the increases in ECF after sweating were as follows: In winter, $16.5 \mathrm{ml} / \mathrm{kg}$ at $13: 00 \mathrm{hr},-5.8 \mathrm{ml} / \mathrm{kg}$ at 16: $00 \mathrm{hr}, 36.9 \mathrm{ml} / \mathrm{kg}$ at $20: 00 \mathrm{hr}(P<0.02)$ and $5.5 \mathrm{ml} / \mathrm{kg}$ at $09: 00 \mathrm{hr}$ and in summer, $31.1 \mathrm{ml} / \mathrm{kg}$ at $13: 00 \mathrm{hr}, 20.5 \mathrm{ml} / \mathrm{kg}$ at $16: 00 \mathrm{hr}, 17.2 \mathrm{ml} / \mathrm{kg}$ at $20: 00 \mathrm{hr}$ and $5.8 \mathrm{ml} / \mathrm{kg}$ at $09: 00 \mathrm{hr}$. The statistical significance was found only on the increase at 20:00 hr in winter.

For the experiment in summer, the amount of water in the whole blood and plasma, calculated from the volumes of circulating blood and plasma, and the water contents of the whole blood and plasma are shown in Fig. 6 together with the CBV and CPV. The whole blood water content decreased by $1.77 \%$ at 13: $00 \mathrm{hr}(P<0.001), 1.09 \%$ at $16: 00 \mathrm{hr}(P<0.001), 0.4 \%$ at $20: 00 \mathrm{hr}(P<0.05)$ 


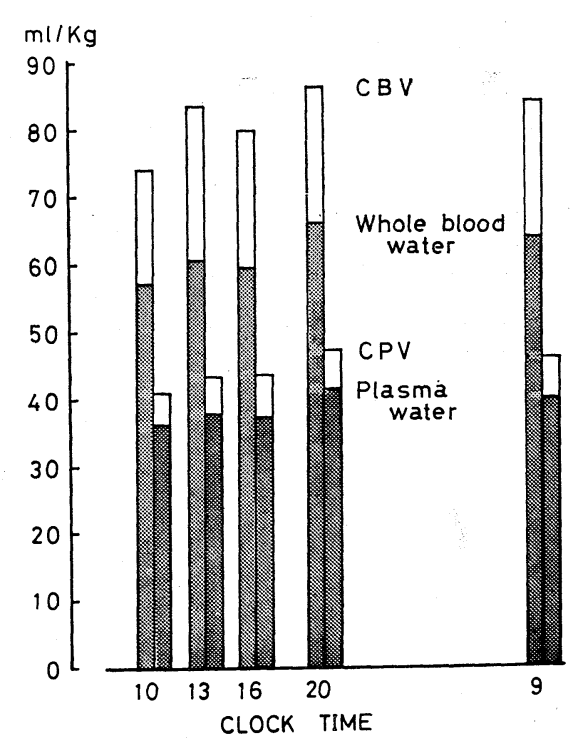

Fig. 6. Changes in circulating blood volume (left column) and circulating plasma volume (right column). Results were obtained in summer on ten subjects. The heights of dotted areas indicate amounts of water in CBV and CPV while those of open columns indicate amount of solids in whole blood and plasma.

and $0.3 \%$ at $09: 00 \mathrm{hr}$ (not significant). Nevertheless, the amount of water in the circulating blood increased by $6.3 \%$ at $13: 00 \mathrm{hr}, 5.9 \%$ at $16: 00 \mathrm{hr}, 18.8 \%$ at $20: 00 \mathrm{hr}$ and $14.5 \%$ at $09: 00 \mathrm{hr}$, though none of those increases were significant. The plasma water content decreased by $1.1 \%$ at $13: 00 \mathrm{hr}(P<0.001)$ and $0.4 \%$ at $16: 00 \mathrm{hr}(P<0.001)$. On the other hand, the amount of water in the circulating plasma increased by $4.6 \%$ at $13: 00 \mathrm{hr}, 5.0 \%$ at $16: 00 \mathrm{hr}, 17.8 \%$ at 20: $00 \mathrm{hr}$ and $13.6 \%$ at $09: 00 \mathrm{hr}$.

To analyze the influences of sweat loss and water intake on the body fluid compartments and on the blood constituents, the correlations were calculated between sweat loss during heat exposure or water intake and the magnitudes of changes in the various items measured and the results in the two experiments are listed in Tables 1 and 2.

In winter (Table 1), the effects of sweating especially on the TBW lasted until the following morning. The significant correlation between sweat loss and the hematocrit observed at 13:00 hr became insignificant at 16:00 and 20:00 hr, but the following morning, a highly significant correlation was observed. The effect of sweating on the serum sodium concentration was also observed in the following morning (09:00 hr). In the evening, when subjects were allowed to take water freely, they drank almost all they wanted before $20: 00 \mathrm{hr}$, but took only a little between $20: 00 \mathrm{hr}$ and $24: 00 \mathrm{hr}$. The effect of water intake be- 
Table 1. Correlations between sweat loss or water intake and deviations from resting values of various items measured in winter.

\begin{tabular}{clrlrc}
\hline \multirow{2}{*}{ Time } & \multicolumn{2}{c}{ Correlation between } & $\begin{array}{c}\text { Correlation } \\
\text { coefficient } \\
r\end{array}$ & $\begin{array}{c}\text { Significance } \\
\text { of } r \\
P\end{array}$ \\
\hline \multirow{2}{*}{$13: 00$} & Sweat loss* & $\&$ & Total body water & -0.840 & $<0.01$ \\
& Sweat loss & $\&$ & Hematocrit & 0.657 & $<0.05$ \\
\hline $16: 00$ & Sweat loss & $\&$ & Total body water & -0.899 & $<0.01$ \\
\hline $20: 00$ & Sweat loss & $\&$ & Total body water & -0.669 & $<0.05$ \\
\hline \multirow{2}{*}{$9: 00$} & Sweat loss & $\&$ & Hematocrit & 0.937 & $<0.01$ \\
& Sweat loss & $\&$ & Serum Na & 0.786 & $<0.01$ \\
& Sweat loss & $\&$ & Total body water & -0.644 & $<0.05$ \\
& Water intake** $\&$ Interstitial fluid volume & -0.637 & $<0.05$ \\
& Water intake & $\&$ & Extracellular fluid volume & -0.634 & $<0.05$ \\
\hline
\end{tabular}

* Sweat loss during 90 min of heat exposure in grams.

** Water intake between 16:00 hr and 24:00 hr in ml.

Table 2. Correlations between sweat loss or water intake and deviations from resting values of various items measured in summer.

\begin{tabular}{llrlcc}
\hline Time & & & Correlation between & $\begin{array}{c}\text { Correlation } \\
\text { coefficient } \\
r\end{array}$ & $\begin{array}{c}\text { Significance } \\
\text { of } r \\
P\end{array}$ \\
\hline 13:00 & Sweat loss* & $\&$ & Circulating plasma volume & -0.783 & $<0.01$ \\
\hline $16: 00$ & Sweat loss & $\&$ & Serum K & 0.779 & $<0.01$ \\
\hline $20: 00$ & Water intake** & $\&$ & Plasma water content & 0.818 & $<0.01$ \\
& Water intake & $\&$ & Serum Na & 0.787 & $<0.01$ \\
\hline \multirow{2}{*}{ 9:00 } & Water intake & $\&$ & Extracellular fluid volume & 0.806 & $<0.01$ \\
& Water intake & $\&$ & Interstitial fluid volume & 0.798 & $<0.01$ \\
& Water intake & $\&$ & Blood water content & 0.742 & $<0.05$ \\
& Water intake & $\&$ & Hematocrit & -0.668 & $<0.05$ \\
& Water intake & $\&$ & Plasma water content & 0.661 & $<0.05$ \\
\hline
\end{tabular}

*, ** Same as in Table 1.

tween 16:00 hr and 24:00 hr on the ISF and ECF were observed in the following morning (09:00 hr). In summer (Table 2), the effects of sweating were observed only on the CPV at 13:00 hr and serum potassium at 16:00 hr, and no significant correlation was observed thereafter. On the other hand, the effect of water intake on the plasma water content and serum sodium were already observable at 20:00 hr and on the following morning, significant correlations were seen between water intake and the ECF, ISF, blood water content, hematocrit and plasma water content. 


\section{DISCUSSION}

One of the main object of the present work was to compare the responses of body fluids to heat stress in summer and winter by measuring the changes in volumes of body fluid compartments and properties of the blood.

The time courses of the responses of blood constituents and their seasonal differences are striking. The serum electrolyte concentrations showed different responses in the two seasons. In winter, the sodium and chloride concentrations in the serum were higher at 16:00 hr, while in summer, the maximum responses were observed at 13:00 hr. One reason for this seasonal difference might be a higher sweat rate in summer. A more important reason may be a facilitated movement of body water and its constituents between the body fluid compartments in summer, which is obvious from the fact that sodium and chloride in serum show maximal increases soon after the sweating in summer, while, in winter, it is observed only $3 \mathrm{hr}$ after the cessation of sweating (Fig. 2). It is also obvious from the correlations between sweat loss or the amount of water intake and responses of the body fluids shown in Tables 1 and 2. MACFARLANE et al. (1966) reported that the turnover rate of water in man increased on acclimatization to heat and the present results also indicate a higher turnover rate of water in summer than in winter. Reported higher levels of $\mathrm{ADH}$ and aldosterone in summer may be involved in the mechanism of these seasonal differences (MACFARLANE et al., 1958; Yoshimura, 1960; Morimoto et al., 1969).

The hematocrit and blood water content showed maximum changes at 13: $00 \mathrm{hr}$ and returned to almost control values at 16:00 hr. Their maximum responses observed at 13:00 hr were almost identical in the two seasons, although the sweat rate was very much higher in summer. Other interesting observations on change in the blood and in the CPV were that hemoconcentration and increase in the CPV were observed simultaneously ( $c f$. Fig. 6) and that the parameters which are commonly used to indicate the degree of hemoconcentration did not show any parallelism. For example, at 13:00 hr, in summer the following deviations were observed from control values: Decrease in the whole blood water content by $1.8 \%$ and increases in the serum osmolality by $2.4 \%$, the hematocrit by $2.9 \%$, plasma protein by $9.2 \%$ and the CPV by $16.8 \%$. This suggests that much more disproportionate changes in the $\mathrm{CPV}$, hematocrit and plasma protein occur during heat stress than those reported in man during exercise (BEAUMONT et al., 1972). As to the changes of body fluid compartments, BASS and HeNSCHEL (1956) concluded in their review that acute heat stress elicits responses which, in the absence of dehydration, would result in increased plasma and blood volumes, with little change in composition. In summarizing the results of the present experiments, it can be said that under slightly dehydrated conditions, blood volume tends to increase with an increase in serum osmolality, expecially in summer. In other body fluid compartments under acute heat stress, only a few studies have 
been reported and their results are controversial (BASS and HenSCHEL, 1956). Even with the newer radioactive isotope methods used in this experiment, the values obtained varied considerably and statistical differences were found only in results at 20:00 hr, but when the mean values for the ten subjects were compared, tendencies for the ECF and ISF to increase and the ICF to decrease were observed.

Another striking feature observed in this work was that water balance was accurately regained within the day of the experiment. This may be explained by the hypothesis of "the skin chloride shift in sweating" proposed by KUNO (1956). According to this hypothesis, chloride is reabsorbed from precursor sweat and accumulated in the interstitial spaces of the skin during active sweating. This accumulation of chloride in interstitial spaces of the skin serves to counteract abrupt rise of chloride in the blood. After active sweating stops, the accumulated chloride is carried away from the skin to the blood stream through the lymph channels. This hypothesis is also in accordance with the phenomenon known as progressive dehydration or voluntary dehydration in which the sensation of thirst does not occur during profuse sweating but only after sweating stops. Reabsorption of ions from precursor sweat should involve reabsorption of both sodium and chloride. Thus the concentration of sodium in the serum and interstitial spaces of the skin should also change, but little attention has been paid to this. The present results show that after sweating serum sodium increased much more than chloride. In winter the increase in the serum sodium concentration after sweating was $1.4 \mathrm{mEq} /$ liter while chloride remained unchanged, and in summer the increase in sodium was $1.2 \mathrm{mEq} /$ liter more than that of chloride. This difference might be partly due to a higher rate of reabsorption of sodium than that of chloride, because the difference in concentrations between sodium and chloride seldom exceed by $10 \mathrm{mEq} /$ liter in sweat (MоRIмOTO and JOHNSON, 1967), while that in serum or in precursor sweat is about $30 \mathrm{mEq} /$ liter (ScHulz et al., 1965) In other words, reabsorption of sodium is higher than that of chloride by about $20 \mathrm{mEq} /$ liter. Another important mechanism preventing the elevation in serum chloride might be the elevation of plasma protein after sweating which prevents elevation of serum chloride by Donnan equilibrium. The retention of chloride in tissue fluid may very well buffer the increase in serum osmolality and such a buffering action on osmolality may partly explain the mechanism to cause so called voluntary dehydration in which thirst sensation does not occur during profuse sweating.

To depict the overall picture, beside the present results, simultaneous measurements should be made on hormones and on the circulatory system (Bowell et al., 1967; Wyndham et al., 1968). However, on the basis of the present results, the mechanism of regulation of body fluid under heat stress might be summarized as follows: Active sweating causes increased osmolality of the ECF, which causes transfer of cellular water to the ECF. An increase 
in plasma protein causes an expansion of the CPV as a result of transfer of water from the ISF, and also causes voluntary dehydration retaining chloride in tissue fluid, and these mechanisms occur more readily in summer than in winter.

This work was supported by a grant from the Ministry of Education.

\section{REFERENCES}

Albert, S. N., Shibuya, J., Economopoulos, B., Radice, A., Cuevo, N., Varrone, E. V., and Albert, C. A., (1968) Simultaneous measurement of erythrocyte, plasma and extracellular fluid volumes with radioactive tracers. Anesthesiology, 29: 908-916.

Arnett, E. M. and Duggleby, P. MCC. (1963) A rapid and simple method of deuterium determination. Anal. Chem., 35: 1420-1424.

BAss, D. E. and Henschel, A. (1956) Responses of body fluid compartments to heat and cold. Physiol. Rev., 36: 128-244.

Beaumont, W. van, Greenleaf, J. E., and Juhos, L. (1972) Disproportional changes in hematocrit, plasma volume, and proteins during exercise and bed rest. J. Appl. Physiol., 33: 55-61.

Bowell, L. B., Kraning II, K. K., Kennedy, J. W., and Evans, T. O. (1967) Central circulatory responses to work in dry heat before and after acclimatization. J. Appl. Physiol., 22: 509-518.

Cardus, D., McTaggart, W. G., and Young, C. L. (1969) Effect of exercise on determination of total body water by tritium oxide. J. Appl. Physiol., 27: 1-3.

Glickman, N., Hick, E. K., Keeton, R. W., and Montgomery, M. M. (1941) Blood volume changes in men exposed to hot environmental conditions for a few hours. Am. J. Physiol., 134: $165-176$.

Iтон, S. (1953) The water loss and blood changes by prolonged sweating without intake of food and drink. Jap. J. Physiol., 3: 148-156.

Kuno, Y. (1956) Human Perspiration. CC. Thomas, Springfield, Illinois, pp. 301-308.

Kuroda, K. (1969) Biological and Medical Studies on Blood Water. Igaku Shoin, Tokyo, pp. 7-18.

LADELL, W. S. S. (1949) The changes in water and chloride distribution during heavy sweating. J. Physiol., 108: 440-450.

MacFarlane, W. V., Robinson, K., Howard, B., and Kinne, R. (1958) Heat, salt and hormones in panting and sweating animals. Nature, 182: 672-673.

MacFarlane, W. V., Howar, B., Morrison, J. F., and Wyndham, C. H. (1966) Content and turnover of water in Bantu miners acclimatizing to humid heat. J. Appl. Physiol., 21: 978984.

Morimoto, T. and Johnson, R. E. (1967) Ammonia and the regulation of acidity in human eccrine sweat. Nature, 216: 813-814.

Morimoto, T., Shiraki, K., Inoue, T., and Yoshimura, H. (1969) Seasonal variation of water and electrolyte in serum with respect to homeostasis. Jap. J. Physiol., 19: 801-813.

Schulz, I., Ullrich, K. J., Frömter, E., Hozgreve, H., Frick, A., und Hegel, U. (1965) Mikropunktion und elektrische Potentialmessung an Schweissdrüsen des Menschen. Pflügers Arch., 284: 360-372.

Senay, L. C., Jr. and Christensen, M. L. (1965) Changes in blood plasma during progressive dehydration. J. Appl. Physiol., 20: 1136-1140.

SenAy, L. C., Jr. and Christensen, M. L. (1968) Variations of certain blood constituents during acute heat exposure. J. Appl. Physiol., 24: 302-309.

SENAY, L. C., Jr. (1968) Relationship of evaporative rates to serum $\mathrm{Na}^{+}, \mathrm{K}^{+}$, and osmolality in 
acute heat stress. J. Appl. Physiol., 25: 149-152.

SENAY, L. C., Jr. (1970) Movement of water, protein and crystalloids between vascular and extravascular compartments in heat-exposed men during dehydration and following limited relief of dehydration. J. Physiol., 210: 617-636.

SENAY, L. C., Jr. (1972) Changes in plasma volume and protein content during exposures of working men to various temperatures before and after acclimatization to heat: Separation of the roles of cutaneous and skeletal muscle circulation. J. Physiol., 224: 61-81.

Shiraki, K., Inoue, T., Morimoto, T., Sweki, M., and Okamoto, T. (1968) Blood volume determination by Volêmetron (RISA-131)). In Proceedings of the 8th Conference on Radioisotopes. Japan Atomic Industrial Forum, Inc., Tokyo, pp. 371-373.

Simpson, J. D. and Greening, J. R. (1960) Preparation of tritiated water samples by distillation. Nature, 186: 467-468.

Wyndham, C. H., Benade, A. J. A., Williams, C. G., Strydom, N. B., Goldin, A., and Heyns, A. J. A. (1968) Changes in central circulation and body fluid spaces during acclimatization to heat. J. Appl. Physiol., 25: 586-593.

Yoshimura, H. (1958) Seasonal changes in human body fluids. Jap. J. Physiol., 8: 165-179.

Yoshimura, H. (1960) Acclimatization to heat and cold. In Essential Problems in Climatic Physiology, ed. by Yoshimura, H., Ogata, K., and Iтoh, S. Nankodo, Kyoto, pp. 61-106. 